\title{
Occurrence of Five Thrips Species on Flue-Cured Tobacco and Impact on Spotted Wilt Disease Incidence in Georgia
}

\author{
R. M. McPherson, Department of Entomology, H. R. Pappu, Department of Plant Pathology, and D. C. Jones, \\ Department of Entomology, University of Georgia, Coastal Plain Experiment Station, Tifton 31793
}

\begin{abstract}
McPherson, R. M., Pappu, H. R., and Jones, D. C. 1999. Occurrence of five thrips species on fluecured tobacco and impact on spotted wilt disease incidence in Georgia. Plant Dis. 83:765-767.

Thrips-vectored tomato spotted wilt tospovirus (TSWV) infection is a major constraint on tobacco production in Georgia. Flue-cured tobacco fields were surveyed throughout the season from 1989 to 1991 and 1996 to 1998 to determine spotted wilt disease incidence and seasonal abundance and species composition of thrips populations. Five species were commonly found that accounted for more than $95 \%$ of the 17,000 thrips collected, including Frankliniella fusca, $F$. occidentalis, F. bispinosa, F. tritici, and Limothrips cerealium. F. fusca, F. occidentalis, and F. bispinosa are vectors of TSWV. F. fusca was the most common foliage thrips collected during all years, except 1989, when L. cerealium was the most abundant species. During 1989 to 1991 , 22 to $68 \%$ of the foliage and flower thrips identified were TSWV vector species. The 1996 to 1998 foliage collections had much higher percentages of vector species (95 to 97\%). The 1996 flower samples also had a very high percentage of vector species $(94 \%)$; however, the percentages were much lower in 1997 (3\%) and 1998 (32\%). A trend toward higher incidence of TSWV occurred during the last three seasons studied, when thrips vector species were more abundant.
\end{abstract}

Additional keywords: ELISA, tobacco thrips, virus detection, western flower thrips

Spotted wilt disease, caused by tomato spotted wilt tospovirus (TSWV), is an economically important problem on tobacco crops in Georgia. First reported in 1986 (5), disease incidence gradually has increased during recent years, with individual fields showing $80 \%$ disease incidence. Spotted wilt disease caused a $17.5 \%$ statewide loss in plant stands and $\$ 12.7$ million in losses to crops in 1997 (2).

TSWV is transmitted by several thrips species. The virus must be acquired by thrips larva in which it multiplies and survives through the larval developmental stages $(9,14)$. Mature adults become viruliferous and remain so for life (14). Adults that feed on infected plants may ingest the virus but cannot transmit it due to the presence of a midgut barrier (14).

Forty-three thrips species have been found on flue-cured tobacco foliage and blooms in Georgia (6), of which three are reported vectors of TSWV: tobacco thrips, Frankliniella fusca (Hinds) (12); western flower thrips, F. occidentalis (Pergande) (11); and F. bispinosa (Morgan) (15). To effectively control these species and the virus they vector requires an understanding of their

Corresponding author: R. M. McPherson E-mail: pherson@tifton.cpes.peachnet.edu

Accepted for publication 11 May 1999.

Publication no. D-1999-0604-01R

(C) 1999 The American Phytopathological Society seasonal abundance and the crop phenology that exists when damaging thrips populations occur. Although the seasonal dynamics of thrips species have been reported in peanut $(3,8,13)$ and tomato $(10)$, information is limited on the abundance of thrips on fluecured tobacco, thrips species present, and incidence of TSWV vectors throughout the season.

Our study was conducted to determine the seasonal incidence of the common thrips species found on flue-cured tobacco, document the percentage of thrips capable of transmitting spotted wilt virus, and relate the incidence of TSWV to the abundance of known thrips vector species. Preliminary results were published previously (7).

\section{MATERIALS AND METHODS}

During 1989 to 1991 and 1996 to 1998, two flue-cured tobacco fields in Tift County, GA, were sampled for thrips every 7 to 10 days beginning just after transplanting in middle to late March and continuing until late June or early July. In 1989, 'NC 2326' tobacco was transplanted at both sites; in 1990, 'Coker 371 Gold' and 'McNair 944' were transplanted; and in 1991 and subsequent years, 'K326' was transplanted at both test sites. Test fields were located at the Coastal Plain Experiment Station and the Bowen Research Farm and ranged in size from 0.6 to 1.0 ha. Production practices were performed according to Georgia Cooperative Extension Service recommendations (4) and included a preplant incorporated tank mix of prebulate (Tillan) and napropamide (Devrinol) for weed control, metalaxyl (Ridomil) for blue mold control, fenamiphos (Nemacur) for nematode suppression, and chlorpyrifos (Lorsban) for soil insect control. Fertilizer (6-6-18, N-P-K) was applied at a rate of $1,122 \mathrm{~kg} / \mathrm{ha}$ in a split application. No foliar insecticides were applied at thrips collection sites, unless tobacco budworm (Heliothis virescens (Fabricius)) or hornworm (Manduca sexta (L.)) populations caused significant defoliation, in which case Dipel $2 \mathrm{X}$ or DF (Bacillus thuringiensis) was applied.

All foliage from 100 to 200 plants was examined visually for thrips at both sites early in the growing season during each year, when thrips populations were low. Later in the season (usually beginning during the middle of April), 20 to 30 plants were sampled at each site. As plants bloomed (beginning in May), all blooms on the terminal floral branch of 10 plants were observed for thrips. Each bloom initially was shaken over a white background, then torn open and shaken again. Bloom sampling continued until all plants were topped. All observed thrips were collected with a fine artist's brush and placed in a vial containing $70 \%$ ethyl alcohol, returned to the laboratory, and identified. During 1996, 1997, and 1998, on alternate collection dates, thrips were placed in phosphate-buffered saline containing $2 \%$ polyvinyl pyrrolidone and $0.02 \%$ sodium azide, identified, and assayed by enzyme-linked immunosorbent assay (ELISA) to determine the presence of nonstructural (NS) TSWV proteins (1). The 1996 thrips samples were sorted by species, and 10 thrips were used per well in a microtiter plate, whereas thrips collected during 1997 and 1998 were individually processed. Thrips reared without access to TSWV served as negative controls. In composite thrips samples, a positive ELISA response indicated the thrips (or at least 1 of 10 thrips in 1996) was capable of transmitting TSWV (1).

All plants in each field were examined visually weekly for spotted wilt disease symptoms. Depending on the size of the plot ( 0.6 to 1 ha.), the number of plants examined for symptoms varied from 8,800 to 14,800 . Foliar symptoms indicative of spotted wilt disease included necrotic lesions and veinal necrosis. Infected plants often were stunted and sometimes showed necrotic streaks on the stem (5). Infection at the seedling stage often resulted in plant death. Symptomatic plants were flagged and dated, 
Table 1. Number of each thrips tomato spotted wilt tospovirus (TSWV) vector species collected on flue-cured tobacco foliage and blooms in Georgia during 1989-1996

\begin{tabular}{lrrrr}
\hline Year & F. fusca & F. bispinosa & F. occidentalis & Other $^{\mathbf{a}}$ \\
\hline No. of thrips collected on foliage & & & & \\
$1989(21.9)^{\mathrm{b}}$ & 79 & 14 & 2 & 337 \\
$1990(64.7)$ & 1,893 & 58 & 22 & 1,076 \\
$1991(63.6)$ & 680 & 29 & 1 & 407 \\
$1996(96.7)$ & 1,996 & 0 & 21 & 67 \\
$1997(97.5)$ & 756 & 9 & 0 & 19 \\
$1998(94.7)$ & 5,617 & 4 & 40 & 319 \\
No. of thrips collected on blooms & & & & \\
$1989(63.7)$ & 0 & 176 & 15 & 109 \\
$1990(57.5)$ & 18 & 837 & 385 & 918 \\
$1991(67.8)$ & 3 & 713 & 8 & 343 \\
$1996(94.4)$ & 5 & 0 & 199 & 12 \\
$1997(3.6)$ & 2 & 6 & 2 & 279 \\
$1998(47.2)$ & 8 & 4 & 73 & 180 \\
\hline
\end{tabular}

a Other thrips species were primarily $F$. tritici and $L$. cerealium, which are not vectors of TSWV. Thrips numbers reported for 1989 to 1991 are summarized from an earlier report (6).

${ }^{b}$ Percentage of all thrips collected that were vector species of TSWV.

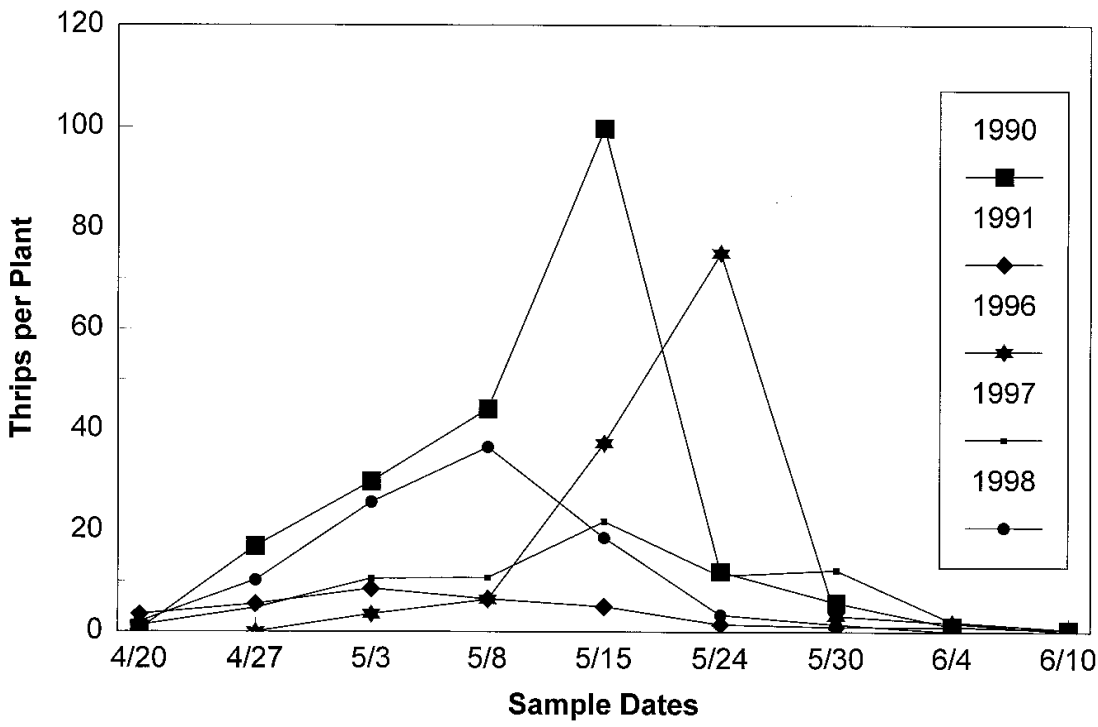

Fig. 1. Seasonal abundance of foliage thrips on flue-cured tobacco at the Coastal Plain Experiment Station, Tift County, GA.

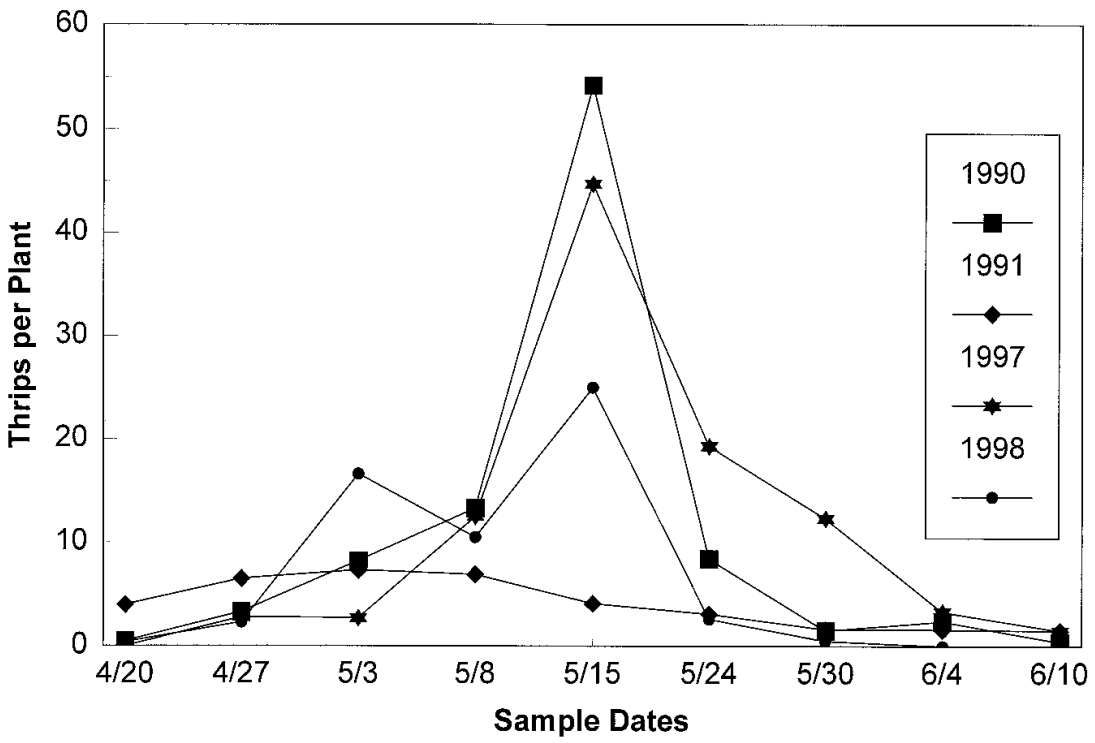

Fig. 2. Seasonal abundance of foliage thrips on flue-cured tobacco at the Bowen Research Farm, Tift County, GA. and the cumulative percentage of infected plants was determined. To confirm a diagnosis of TSWV, representative symptomatic plants were tested by ELISA with a commercial kit (Agdia, Elkhart, IN).

\section{RESULTS AND DISCUSSION}

More than 17,000 thrips specimens were identified on flue-cured tobacco during our 6-year study. F. fusca was the most common foliage thrips observed every year, except 1989, when L. cerealium was the most abundant species. Interestingly, L. cereali$u m$ was very common on tobacco foliage during 1989 to 1991, but very low numbers (less than 100 total) were observed during 1996 to 1998. Some F. occidentalis and F. bispinosa also were observed on tobacco foliage each year. During 1989 to 1991 , these three Frankliniella spp. comprised 22,65 , and $64 \%$ of the total thrips complex counted on tobacco foliage (Table 1). During 1996 to 1998 , the three TSWV vectors made up 95 to $97 \%$ of the total thrips population. The dramatic increase in the overall percentage of vector species in the population probably was due to a vast reduction in the numbers of $L$. cerealium present during 1996 to 1998.

The percentage of vector species collected from tobacco blooms ranged from 3 to $94 \%$ during the 6 years of this study. Of the thrips complex from 1989 to 1991,57 to $68 \%$ was made up of vector species, primarily high numbers of $F$. bispinosa. The high percentage of vector species in 1996 (94\%) was due to the predominance of $F$. occidentalis, when no $F$. bispinosa were found. In 1997 and 1998, fewer F. occidentalis and $F$. bispinosa were found. Instead, $F$. tritici, which is not a vector, was much more abundant. Thus, a much lower percentage of the thrips complex was composed of vector species during these 2 years (Table 1).

ELISA indicated that none of the $100 \mathrm{~F}$. fusca (10 sets of 10 thrips each) collected 2 weeks after transplant were positive for TSWV NS. At 4 weeks after transplant, 15 of 30 sets of 10 thrips (50\%) tested positive, indicating at least $1 \mathrm{~F}$. fusca in each set of 10 was transmitting TSWV, because ELISA is capable of detecting NS protein in a single adult insect $(1,9)$. Even if only 1 thrips in each of the 15 positive samples was a vector, it would equate with 15 transmitters of 300 thrips tested or $5 \%$ of the population. In 1997 and 1998, 3.5 to 4.6\% of the individual $F$. fusca tested were positive for TSWV NS, respectively. The seasonal dynamics of thrips transmitters in peanut fields showed that $\approx 8 \%$ of $F$. fusca were potential transmitters of TSWV (9).

Field population densities of thrips were low during the first 4 weeks after transplanting, after which they rapidly increased from late April to the middle of May at both the Coastal Plain Experiment Station (Fig. 1) and Bowen Research Farm (Fig. 2) locations. Peak populations occurred between 


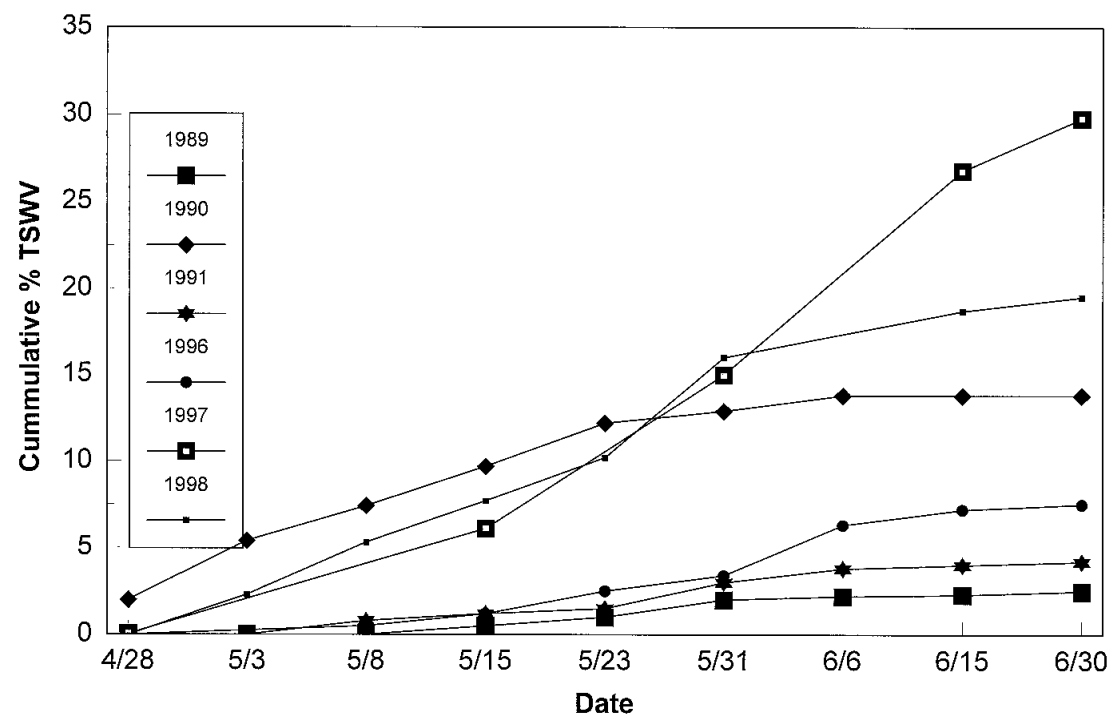

Fig. 3. Seasonal incidence of spotted wilt disease of symptomatic flue-cured tobacco plants.

3 and 24 May at both locations during all 6 years, after which populations rapidly dropped to low levels when tobacco began to flower. Peak populations ranged from 8.5 to 99.7 thrips per plant among years and between locations (99.7 at the Coastal Plain Experiment Station and 54.2 at the Bowen Farm).

The seasonal incidence of spotted wilt disease for each year of our study (average of both locations) is presented in Figure 3. Very few symptomatic plants were observed at either location until late April (5 to 6 weeks after transplanting), after which the cumulative percentage of infected plants steadily rose, peaking at $2.5,13.6$, and $4.2 \%$ during 1989, 1990, and 1991, respectively, and 8.4, 29.8, and 19.5\% during 1996, 1997, and 1998, respectively. Only minor increases in the cumulative percentage of TSWV incidence were observed after 31 May, except in 1997, when incidence rose from $15 \%$ on 31 May to nearly $30 \%$ on 30 June. Average plant stand loss due to TSWV was 1 to $17.5 \%$ during 1988 to 1998 ; the highest loss $(17.5 \%)$ was in 1997.

There has been a trend toward higher incidence of TSWV in flue-cured tobacco in Georgia. During this period of increased disease incidence, there has been a dramatic shift in the thrips species complex composition, including a higher percentage of vector species. In particular, F. fusca has become the dominant species on tobacco foliage, while populations of $L$. cerealium (a nonvector species) have declined. Knowing which vector species are present and the seasonal abundance of these pests will aid the development of effective strategies for managing spotted wilt disease in fluecured tobacco.

\section{ACKNOWLEDGMENTS}

We thank B. Crowe, K. Lewis, D. Taylor, and W. Tillery for their technical assistance; D. Ullman (University of California at Davis) for supplying TSWV-negative and -positive thrips species used in ELISA tests; J. L. Sherwood (University of Georgia) for the NSs antibody; the Philip Morris Tobacco Company, the Georgia Agricultural Commodity Commission for Tobacco, and the University of Georgia Agricultural Experiment Stations for financial support of this project.

\section{LITERATURE CITED}

1. Bandla, M. D., Westcot, D. M., Chenault, K. D., Ullman, D. E., German, T. L., and Sherwood, J. L. 1994. Use of monoclonal antibody to the nonstructural protein encoded by the small RNA of tomato spotted wilt tospovirus to identify viruliferous thrips. Phytopathology 84 : 1427-1431.

2. Bertrand, P. 1998. 1997 Tobacco disease losses. Univ. Ga. Coop. Ext. Serv. Publ. 1-98:4.

3. Chamberlin, J. R., Todd, J. W., Beshear, R. J., Culbreath, A. K., and Demski, J. W. 1992.
Overwintering hosts and wingform of thrips, Frankliniella spp. in Georgia (Thysanoptera: Thripidae): Implications for management of spotted wilt disease. Environ. Entomol. 21:121128.

4. Cooperative Extension Service. 1996. Georgia Tobacco Grower's Guide. Publication CSS96-02. University of Georgia, College of Agricultural and Environmental Sciences, Athens.

5. Culbreath, A. K., Csinos, A. S., Bertrand, P. F., and Demski, J. W. 1991. Tomato spotted wilt epidemic in flue-cured tobacco in Georgia. Plant Dis. 75:483-485.

6. McPherson, R. M., Beshear, R. J., and Culbreath, A. K. 1992. Seasonal abundance of thrips (Thysanoptera: Suborders Terebrantia and Tubulifera) in Georgia flue-cured tobacco and impact of management practices on the incidence of tomato spotted wilt virus. J. Entomol. Sci. 27:257-268.

7. McPherson, R. M., Pappu, H. R., and Jones, D. C. 1998. Distribution of thrips on flue-cured tobacco and impact on the incidence of spotted wilt in Georgia. Proc. 1998 CORESTA Congr. Co-operation Center for Scientific Research Relative to Tobacco, Brighton, England.

8. Pappu, H. R., Todd, J. W., Culbreath, A. K., Bandla, M. D., and Sherwood, J. L. 1997. Detection and seasonal dynamics of tomato spotted wilt virus-transmitters in populations of tobacco thrips and western flower thrips in peanut. (Abstr.) Phytopathology 87(suppl):S74.

9. Pappu, H. R., Todd, J. W., Culbreath, A. K., Bandla, M. D., and Sherwood, J. L. 1998. First report on the multiplication of tomato spotted wilt tospovirus in tobacco thrips, Frankliniella fusca. Plant Dis. 82:1282.

10. Puche, H., Berger, R. D., and Funderburk, J. E. 1995. Population dynamics of Frankliniella species (Thysanoptera: Thripidae) and progress of spotted wilt in tomato fields. Crop Prot. 14:577-583.

11. Sakimura, K. 1962. Frankliniella occidentalis (Thysanoptera: Thripidae), a vector of the tomato spotted wilt virus, with special reference to the color forms. Ann. Entomol. Soc. Am. 55:387-389.

12. Sakimura, K. 1963. Frankliniella fusca, an additional vector for the tomato spotted wilt virus, with notes on Thrips tabaci, another vector. Phytopathology 53:412-415.

13. Todd, J. W., Culbreath, A. K., Chamberlin, J. R., Beshear, R. J., and Mullinix, B. G. 1995 Colonization and population dynamics of thrips in peanuts in the southern United States. Pages 453-460 in: Thrips Biology and Management. B. L. Parker, M. Skinner, and T. Lewis, eds. Plenum Press, New York.

14. Ullman, D. E. 1996. Thrips and tospoviruses: Advances and future directions. Acta Hortic. 431:310-324.

15. Webb, S. E., Kok-Yokomi, M. L., and Tsai, J. H. 1997. Evaluation of Frankliniella bispinosa as a potential vector of tomato spotted wilt virus. (Abstr.) Phytopathology 87(suppl.):S102. 